\title{
The Contributions of Mentoring on Teachers' Effective Classroom Management Strategies in Government Aided Secondary Schools in the Acholi Sub-Region
}

\author{
John Bismarck Okumu ${ }^{1 *} \quad$ Victoria Tamale Kaggwa ${ }^{2} \quad$ Scott Wycliffe Wafula ${ }^{2}$ \\ 1. Faculty of_Education and Humanities, Gulu University P.O. B OX, 166, Gulu, Uganda \\ 2. School of Education and External studies, Makerere University P.O.BOX 7063, Kampala, Uganda
}

\begin{abstract}
The study investigates the extent to which mentoring services improve on teachers' instructional processes in government aided secondary schools. Teacher effectiveness requires concerted effort and interventions to change the way teachers conduct their teaching. The research used cross sectional survey and mixed methods. Questionnaires and interviews were used to collect data. Data was collected from 462 secondary school teachers and school administrators and analyzed using descriptive statistics and Chi-Square frequency. The results statistically significantly suggested that teachers are able to supervise and control learners during class activities as a result of mentoring services $(M=4.40)$. The study findings statistically significantly suggested $(M=4.32)$ that teachers have acquired skills of controlling learners' behaviours in the class as a result of mentoring services. It was also statistically significantly suggested $(\mathrm{M}=4.25)$ that teachers acquired skills of controlling noise as a result of mentoring services. The findings through quantitative methods revealed that mentoring influence teacher effectiveness in government aided secondary schools. However, findings through qualitative methods revealed that Mentoring does not have any influence on teacher effectiveness. Findings through documents checked revealed that mentoring activities are not documented meaning no mentoring services in the schools. Mentors have not had formal training in mentoring, they have no mentoring skills. This is why teachers do not effectively manage their classroom and students' performance remain poor. The study suggests that Ministry of Education and Sports should be empowered to regularly organize appropriate training for teachers and school administrators to scale-up teachers' awareness and skills in mentoring to help improve on teachers' instructional processes in government aided secondary schools.
\end{abstract}

Keywords: Teacher Effectiveness, teaching, mentoring, classroom management. government aided secondary schools

DOI: $10.7176 / \mathrm{JEP} / 10-36-16$

Publication date: December $31^{\text {st }} 2019$

\section{Introduction}

Teaching can be a daunting endeavor- for both experts and novice teachers. It is a profession that requires the ability to be responsive to new demands and changing needs (Katheleen, 2010). Mentoring is a teaching tool that helps guide both the experienced and inexperienced teachers. It is an interactive process that helps individuals acquire teaching skills based on lesson designs, methods of delivery; stimulating interests in the subject and motivating students to learn more effectively and efficiently thus improving teacher effectiveness (Janas, 1996a; Metros \& Yang, 2006b).

Mentoring guides, the teachers to develop their talents, skills, knowledge, change of attitudes towards effective classroom management. Through mentoring teachers are made to think critically, creatively and become reasonable reflective practitioners. Mentoring means guiding and supporting teachers to ease them through difficult transitions; it is about smoothing the ways, enabling, reassuring as well as directing, managing and instructing(Fletcher, 2000)

According to(Roff, 2012), mentoring is the collaboration between an experienced teacher and a beginning teacher to assist in a variety of aspects relating to the teaching profession. (Wanberg, Kammeyer-Mueller, \& Marchese, 2006; Woolnough, and Davidson, 2007) refer to Mentoring as a process of using specially selected and trained individuals to provide guidance, pragmatic advice, and continuing support that will help the people in their learning and development process change. A mentoring relationship enables teachers to cope with change(Fletcher, 2000) and enables change within teaching too. Classroom management is a more holistic descriptor of teachers' actions in orchestrating supportive learning environments and building community (Evertson,\& Harris, 1999; Katheleen, 2010). However, the most successful teachers approach management as a process of establishing and maintaining effective learning environment.

(Larrivee, 2005) noted that classroom management is a critical ingredient in three-way mix of effective strategies, which includes meaningful content, powerful teaching strategies, and an organizational structure to support productive learning. Teachers are not exposed to high quality classroom management in their coursework (Katheleen, 2010), they learn classroom management practices in schools where they do field 
observations and student learning.

According to, (Katheleen, 2010; Wenger, McDermott \&Snyder, 2002) teachers may attend professional development workshops that deal with management and behaviour issues, or they may initiate learning on their own, seeking out books and materials that offer insight and support for dealing with behaviour and management problems in the classroom.

Although secondary teaching involves intensive interaction with students, the work of teachers is done largely in isolation from colleagues (Ingersoll, 2004).Unfortunately, these responsibilities may lead to new teachers leaving the teaching profession (Hewitt, 2009).

(Metros and Yang, 2006a) define mentoring as helping and supporting people manage their own learning in order to maximize their professional potential, develop their skills, improve their performance and become a person they want to be.

In this study mentoring is defined as a method of helping people acquire skills and knowledge from experienced managers who are wise in the way of improving their teaching -learning process. The main constructs of mentoring are improved professional opportunities, career development, self-awareness among others. There is another perhaps related issue that received less attention but nevertheless a concern for teachers: classroom management and record management strategies. According to (Duck, (2007); Freiberg, (2002); Meister \&Melnick, (2003); Merrett \& Whedall, (1993) and Stoughto,( 2007) new teachers feel unprepared when it comes to classroom management skills and that they are often unprepared to function successfully in today's classrooms with regards to managing administrative tasks, curriculum, record issues and behaviour problems. This was also supported by (Allen\& Blackston, 2003; Bauman \& Del Rio, 2006; Kirkpatric., Lincoln \& Morrow, 2006). It seems that the need for successful classroom management skills has not diminished during a time when school reform has put the spotlight on academic testing and student achievement.

In the Acholi sub- region,, a report from (MOES, 2004) reveals that mentoring has become an extremely popular policy for improving the performance of the teachers in teaching and students management. What perhaps remains a concern is that mentors have not been trained adequately in mentoring process and seem to have negative attitudes towards mentoring in government -aided secondary schools. Teachers continue to be absent from schools and even when they are present at school, they do not enter classes to teach regularly, despite being timetabled to teach. Teachers rarely mark registers, keep records of work covered. In some instances, teachers rarely give exercises and there are scanty records kept on students' progress. They do not pay attention to individual learners behaviour management and records. Teachers supervision of activities are not meaningful. This situation raised concerns on the effect of mentoring on teacher effectiveness classroom management in the region. Secondary school teachers from the Acholi sub-region seem to have negative attitudes towards mentoring as reported by MOES (2003) that many of them do not want to be paired up with mentors; they have low self-awareness on mentoring. Teachers often associate it with supervision and this may consequently make them resist mentoring.

\section{Statement of the problem}

Quality education entirely depends on teachers' effectiveness. Education being the fundamental requisite for one to profoundly contribute to such development, requires quality teaching. Mentoring is a very important institutional tool for the improvement of the teaching process. However, it has been realized that teachers do not respond to mentoring services in government aided secondary schools as an intervention to help improve on their instructional strategies. They have resisted mentoring services yet their teaching process still remains ineffective. The behaviours of teachers indicate that mentoring is resisted in the Acholi sub- region government aided secondary schools, as they say, "We did mentoring before and it did not work: we do not have time and resources"(MOES, 2003). In a comparative study, Hansman (2010) observed that there are instances where mentees actively resist the advice and encouragement given to them by mentors. Kuyini, (2013) asserted that weaknesses are evidenced in the link that has been made between poor quality teaching and poor classroom management. It is realized that little attention is given to mentoring process and yet it is a strategy that is acclaimed for developing teaching skills of teachers and improves the teachers' classroom management strategies in government aided secondary schools.

\section{Purpose of the study}

The purpose of this study was to investigate the contributions of mentoring on teachers' effective classroom management in government- aided secondary schools in the Acholi sub-region.

\section{Specific Objectives}

This study was guided by the following specific objectives:

i) To assess the contributions of mentoring on teachers' effective classroom management in government aided secondary schools in the Acholi sub-region. 
ii) To examine the contributions of mentoring on teachers' effective records management in government aided secondary schools in the Acholi sub-region.

\section{Hypothesis}

i) Mentoring has no influence on teacher effective classroom management strategies in government -aided secondary schools in the Acholi Sub -Region.

\section{Related literature}

Theoretical framework

This study was based on theories of mentoring and teacher effectiveness. The study was grounded in the conceptual framework of Bandura's social cognitive theory, Vygotsky socio-cultural theory, and Knowles's adult learning theory. According to, Bandura (1977), people learn by observing others in action. Another theory associated with this study was Vygotsky's socio-cultural theory, where individuals (beginning teachers) learn from each other through interactions. These theories create foundation for this study. Adults (beginning teachers) must have a working knowledge of how they learn. Mentoring programmes have been well documented in educational research(Ingersoll \& Strong, 2011). Mentoring programmes help beginning teachers deal with the everyday challenges of the classroom and school environments. In a recent study conducted in Uganda by the MOES,(2012) report indicates that over $80 \%$ of classrooms in Universal Secondary Education (USE) were crowded leaving no space for teachers to move around and support students. The same government grant has been received in government aided secondary schools in Acholi sub-region and the number of students has gone high. The researcher, however, observes that most teachers fail to control the class and no proper guidance is given to learners yet if mentoring is used, teachers could control their classes well. Cook, (2010) observed that teacher mentoring foster a relationship of ongoing support, collaboration and the development of knowledge and skills that translate into improved teaching strategies. Studies have shown that teachers who receive mentoring support from experienced teachers during their first years in the classroom increase the rate of developing effective teaching practices Strong, (2005). Brock \& Grady, (2006); Villani, (2009) observed that, the mentoring process exposes new strategies, encourages the sharing of ideas, and promotes an increase in self-confidence in the teachers' own capabilities.

Mentoring might have the capacity to help teachers in sharing ideas which later leads to promotion of selfconfidence, however, the researcher wanted to find out whether mentoring can improve on teacher effective classroom management in government aided secondary schools. Teaching records are very important in teaching, many teachers are expected to have knowledge of record management to guide them effectively.

While mentoring has been shown to benefit the experienced teacher as well as the less experienced, it is implicit that mentoring will contribute to the establishment of the student teachers' norms, attitudes, and standards that will guide their professional practice for years to come (Bartell, 2005), especially teaching records. Evans-Andris, et al, (2006) caution on mentoring programs that solely target the emotional and technical concerns of new teachers. Because new teachers are still shaping their decisions and strategies regarding curriculum and instruction, they need support and guidance in constructing their practice Grossman, \& Thompson, (2004). It is important that mentoring programmes should target all areas of teacher improvement.

In another study Hannon, (2009) reports that teachers and administrators in secondary schools are constantly behind schedule or disrespectful of time, lessons begin late, lunch is served late, students are tardy, meetings run far beyond scheduled time. Hannon, (2009) continued to report that teachers can be guilty of dodging lessons, being late, making excuses and being lazy, some teachers are not working up to their potentials. While Burden, (2003) states, classroom management involves teacher actions to create a learning environment that encourages positive social interactions, active engagement in learning, and self-motivation. Early-career teachers, including pre-service teachers, claim that classroom management can cause significant apprehension Lewis et al., (2005); Putman, (2009). With a growing focus on school-wide approaches to positive behaviour support, Rogers, (2007) noted that early-career teachers need guidance from experienced and respected teachers and leaders. Managing student behaviour is high on the list of priorities for teachers (Australian Education). Of particular concern to teachers is managing relatively low level behaviours Crosswell, (2009), such as students calling out, being off task or refusing to follow instructions. There are many different literatures about teacher effectiveness, yet it was also confirmed that many teachers are always absent from schools and classes, there are no literature reviewed that talked about mentoring services helping teachers to be regularly present in school and classes in government aided secondary schools in Uganda. The researchers observe that there are limited literatures that talk about contributions of mentoring on teacher effective classroom management strategies in government aided secondary schools.

\section{Methodology and materials.}

The study used cross-sectional survey design. It was both qualitative and quantitative. Survey questionnaires, 
interviews and document analysis were the appropriate ways to collect data. The study area was Acholi-subregion which comprises of eight districts both urban and rural. The study focused on Government aided secondary schools of which Gulu district has 9, Omoro 6, Kitgum 8, Pader 7, Agago 6, Amuru 4, Nwoya 4 and Lamwo has 4 schools respectively. Of the 48 schools, 42 were selected using Krejcie and Morgan (1970) table of sampling. The total population was 462. Respondents were sampled using stratified random sampling and purposive sampling techniques. Self-report techniques were used, that included structured questionnaires survey, interviews and documentary analysis. The questionnaires were 5 point Likert scale rated as strongly agree, agree, neither agree nor disagree, disagree, strongly disagree. Other information was collected using interview items and documents analysis. Data were analyzed using descriptive statistics, Chi-Square and frequency of responses within themes were generated.

\section{Findings of the study}

Regarding the question on the contributions of mentoring on teacher effective classroom management strategies in teaching, descriptive statistics on teacher rating was presented in table 1

Table 1: Descriptive statistics about teachers' effective classroom management strategy as a result of mentoring services in government aided secondary schools in the Acholi sub-region

\begin{tabular}{|c|c|c|c|c|c|}
\hline Items about teachers classroom management strategy & $\mathrm{N}$ & Minimum & Maximum & Mean & $\begin{array}{c}\text { Std. } \\
\text { Deviation }\end{array}$ \\
\hline In my school there is conducive learning environment. & 310 & 1 & 5 & 4.10 & .939 \\
\hline $\begin{array}{l}\text { In my class there is collegial relationship between teacher and } \\
\text { learners }\end{array}$ & 310 & 1 & 5 & 4.13 & .806 \\
\hline $\begin{array}{l}\text { I have acquired the skills of controlling students' behaviour } \\
\text { in the class }\end{array}$ & 310 & 1 & 5 & 4.32 & .714 \\
\hline $\begin{array}{l}\text { I am able to supervise and control students during class } \\
\text { activities }\end{array}$ & 310 & 1 & 5 & 4.40 & .716 \\
\hline I have skills of controlling noise both in and out of class & 310 & 1 & 5 & 4.25 & .825 \\
\hline $\begin{array}{l}\text { In my class, there is availability of well-arranged materials } \\
\text { that can promote incidental learning }\end{array}$ & 310 & 1 & 5 & 3.53 & 1.090 \\
\hline Average & & & & 4.12 & 0.848 \\
\hline
\end{tabular}

Source: Primary data, 2017

The results in table 2, statistically significantly suggested that teachers are able to supervise and control learners during class activities as a result of mentoring services $(M=4.40)$. The study findings statistically significantly suggested $(\mathrm{M}=4.32)$ that teachers have acquired skills of controlling learners' behaviours in the class as a result of mentoring services. It was also statistically significantly suggested $(M=4.25)$ that teachers acquired skills of controlling noise as a result of mentoring services. Following the qualitative interview conducted among the Head teachers, Deputy Head teachers and Directors of studies, it was reported that through mentoring teachers have acquired skills of controlling learners' behaviour. One of the Deputy head teachers reported that the teaching skills teachers acquired from the Universities and Colleges were not adequate, however, through mentoring services, teachers' skills improved. For instance, one of the head teachers noted that, Teachers' skills of controlling learners behaviours changed as a results of mentoring, they are able to use various ways of teaching, which control learners behaviours.

It was further reported that most mentors concentrate on students rather than teachers and this had also created some discrepancies in teaching processes. For instance, one of the deputy head teachers reported thus;

At our school, mentoring is done occasionally during the departmental meeting

and once in a term during staff meetings. We also conduct close supervision

of teachers during the teaching process to evaluate their progress.

This implies that on teachers' effectiveness, it is the teachers who manage the learners' behaviours in the classroom, this means that teachers could have acquired the skills through mentoring services. Therefore, it is in order to relate classroom management as aspect of teacher effectiveness to teachers' management of learners' records as shown in table 2. 
Table 2: Descriptive statistics about teachers' management of learners records in government aided secondary schools in the Acholi sub-region

\begin{tabular}{|c|c|c|c|c|c|}
\hline Items about teachers teaching record management & $\mathrm{N}$ & Minimum & Maximum & Mean & $\begin{array}{c}\text { Std. } \\
\text { Deviation }\end{array}$ \\
\hline I regularly keep assessment records in my subject areas & 310 & 1 & 5 & 4.36 & .696 \\
\hline I have record of work covered in this school & 310 & 2 & 5 & 4.27 & .712 \\
\hline $\begin{array}{l}\text { As a teacher I keep records of lesson plans and schemes of } \\
\text { work }\end{array}$ & 310 & 1 & 5 & 4.15 & .773 \\
\hline I write self-evaluation objectively in my lesson plans & 310 & 1 & 5 & 3.97 & .938 \\
\hline Average & & & & 4.19 & 0.780 \\
\hline
\end{tabular}

Source: Primary data, 2017

Table 2. Statistically significantly suggests that teachers strongly agreed $(M=4.36)$ to the view that teachers regularly keep assessment records in their subject areas. On the record of work covered, teachers significantly agreed that they have records of work covered recorded regularly $(M=4.27)$. Teachers statistically significantly suggested that $(\mathrm{M}=4.15)$ keep records of lesson plans and schemes of work. Through the interview, Head teachers, Deputy Head teachers and Directors of studies reported that: Some teachers have record of assessment as a result of mentoring, for example, one Head teacher said thus:

Teachers rarely keep assessment records, they argued that their class sizes are very big that it takes them time to prepare and keep the records of assessments.

This was an indicator that most of the teachers do not keep records of assessments. When the Head teachers, Deputy head teachers and Directors of studies were asked about the quality of the lesson plans of GovernmentAided Secondary schools in Acholi sub-region. For instance, one of the head teachers reported thus,

The lesson plans for senior teachers are good while those for

the teachers in practice are of poor quality or at best satisfactory.

It was further reported by two Head teachers that teachers are lazy in preparing lesson plans in Government Aided Secondary schools. For example, one of the Directors of studies reported that,

Many of the teachers rarely draw lesson plans and majority

of them have forgotten lesson planning in their subject areas.

This implies that lesson plan as an important teaching tool has an impact on the quality of teaching learning process. One Deputy head teachers reported that one can systematically teach learners without lesson plans from the schemes of work. For instance, one Deputy head teachers reported thus;

Lesson plan is a slow method of teaching there is no need for

a teacher to draw lesson plans. Teachers mostly used schemes

of work and lesson notes, most teachers have forgotten lesson plan.

However, most teachers do not perhaps have the interest to prepare lesson plan. Mentoring services help to improve the teachers' skills of lesson preparations thus making meaningful and purposeful lesson plan preparations.

Through qualitative interviews, Head teachers, Deputy head teachers and Directors of studies were asked about teachers' discussion about the strengths and weaknesses with other teachers, they reported the followings: One of the Directors of studies reported that teachers discuss their strengths and weaknesses regularly with other teachers in Government Aided Secondary schools. Two Deputy head teachers reported that many teachers fear to discuss their strengths and weaknesses with their counter parts. For example, one of the directors of studies reported that,

\section{Teachers feel they know all so there is no need discussing strengths}

and weaknesses with other teachers

Head teachers also reported that discussing strengths and weaknesses plays an important role in making teachers improve on their teaching effectiveness in Government Aided Secondary schools. They argued that without discussion of strengths and weaknesses in schools, teachers would not even know how effectively they are teaching. This implies that discussing strengths and weaknesses with other teachers helps to realize their areas of improvement and maintenance in teaching process. The interview responses on teachers' management of teaching records were based on four issues which include, keeping assessment records in subject areas, record of work covered, record of lesson plans and schemes of work and record of self-evaluation. Head teachers, Deputy head teachers and Directors of studies responses indicate that mentoring services has an effect on teachers' management of teaching records. A head teacher reported that teachers keep their teaching records in their subject areas. Another Director of studies reported that some teachers adequately keep their assessment records. Although Head teachers, Deputy head teachers and Directors of studies acknowledged the importance of keeping assessment records, some of them expressed dissatisfaction with the way teachers keep assessment record for 
example, a head teacher reported that there are teachers who do not keep assessment records. One Deputy head teacher also reported thus,

There is a common practice that many teachers do not keep assessment

records in their subject areas because they do not assess learners at all.

This implies perhaps that, mentoring guides teachers who have problems in assessing learners and also keeping assessment records in their subject areas.

The interview conducted reported teachers' management of record of work covered. Head teachers reported that some teachers in government aided secondary schools prepare lesson plans, scheme of work, teach effectively and keep records of work covered, for example one of the deputy head teachers reported that,

\section{Some teachers prepare lesson plans and also prepare end of topics}

results and have files containing the results.

However, another Head teacher also reported that,

Many of the teachers do not prepare lesson plans and also do not have

record of work covered, we have problem guiding teachers in keeping

records of work covered, they are adamant, they prepare schemes of

work but not lesson plans.

Documents checked included lesson plans, schemes of work, records on mentoring. It was reported that teachers hardly draw schemes of work, the few have schemes of work which are not endorsed. The records on mentoring in the schools were not kept, meaning no documentation of mentoring. Head teachers, Deputy head teachers and Directors of studies reported that they were not had formal training for mentoring, they do not have adequate skills.

Records are very important in teaching; many teachers are perhaps expected to have knowledge of record management. Through mentoring services, teachers are expected to keep teaching records to guide them teach effectively. In summary, mentoring guide teachers to teach teacher effectively if teachers follow what the mentors give them in the process of teaching.

This implies that teachers manage their teaching records well as a result of mentoring in Government Aided Secondary schools, or it is probable that teachers keep assessment records which tend to enhance the skills of effective teaching.

\section{Discussion}

The study findings revealed that teachers were able to supervise and control learners during class activities. Teachers' skills of controlling learners' behaviours changed as a result of mentoring, they are able to use various ways of teaching. Through qualitative interviews, the study revealed that teachers' skills of controlling learners' behaviours changed as a result of mentoring. In line with the study by Burden (2003) classroom management involves teacher actions to create a learning environment that encourages positive social interactions, active engagement in learning, and self-motivation. The researcher argues that classroom management issues are very crucial to teachers, they show how effective teachers are, therefore there is high need to have skills in managing classroom for effective implementation of the curriculum.

On the question about teachers' management of teaching records, the study revealed that teachers regularly keep assessment records in their subject areas as a result of mentoring services. The study also revealed through qualitative study that teachers rarely keep assessment records, they argued that their class-size are very big that it takes them time to prepare and keep the records of assessment. In a related study Bartell, (2005), observed that while mentoring has been shown to benefit the experienced teacher as well as the less experienced, it is implicit that mentoring will contribute to the establishment of the student teachers' norms, attitudes, and standards that will guide their professional practice for years to come, especially teaching records. There is a common practice that many teachers do not keep assessment records in their subject areas because they do not assess students at all. This study shows that mentoring focused on the balanced instruction improved teaching practice as measured by observation tool(Stanulis \& Floden, 2009).

The study findings revealed that teachers keep records of work covered as result of mentoring services. The findings were supplemented by qualitative interviews which revealed that, many of the teachers do not prepare lesson plans and also do not have records of work covered, majority have forgotten lesson planning in their subject areas as they say lesson plan is a slow method of teaching there is no need for it. There is a problem guiding teachers in keeping records of work covered, they are adamant, they prepare schemes of work but not lesson plans. In connection to mentoring, Brock \& Grady, (2006); Villani, (2009) observed that, the mentoring process exposes new strategies, encourages the sharing of ideas, and promotes an increase in self-confidence in the teachers' own capabilities. Teaching records are very important in teaching, many teachers are expected to have knowledge of record management to guide them effectively. A study by Evans-Andris, Kyle, \& Carini, (2006) cautions mentoring programs that solely target the emotional and technical concerns of new teachers. It is important that mentoring programmes should target all areas of teacher improvement. The categories of effective 
teaching that composed the intended mentoring curriculum included teaching worthwhile content, classroom management that engages learners and strong motivation and scaffolding of student learning (Stanulis \& Floden, 2009).Mentoring involved close work in the classroom, where mentors observed, co planned analyzed students work, and collected and analysed teaching data together.

It was revealed that all items under teacher effectiveness were having issues such as poor teaching methods and consistent students' poor achievement as a result of in adequate mentoring service among teachers. The summary also revealed that teacher effectiveness was rated very significantly low. Thus teacher effectiveness required some interventions and there is more divergence of views on teacher effectiveness than mentoring.

\section{Conclusion}

The findings through quantitative methods revealed that mentoring influence teacher effectiveness in government aided secondary schools. However, findings through qualitative methods revealed that Mentoring does not have any influence on teacher effectiveness. Findings through documents checked revealed that mentoring activities are not documented meaning no mentoring services in the schools. Mentors have not had formal training in mentoring, they have no mentoring skills. This is why teachers do not teach effectively and students performance remain poor. Teachers beliefs, knowledge, ideas and practices with regard to classroom management are affected by the social context of the secondary schools and by the teachers' contact with one another through mentoring process. The study suggests that Ministry of Education and Sports should be empowered to regularly organize appropriate training for teachers and school administrators to scale-up teachers' awareness and skills in mentoring to help improve on teachers' instructional processes in government aided secondary schools.

\section{References}

Allen, S.,\& Blackston, A. R. (2003). Training preservice teachers in collaborative problem solving: An investigation of the impact of teacher and student behaviour change in real-world settings. School Psychology Quarterly, 18(1), 22-51.

Bandura, A. J. (1977). social learning theory. New York,NY: General Learning Press.

Bartell, C. A. (2005). Cultivating high - quality teaching through induction and mentoring . Thousand Oaks, CA: Corwin Press.

Bauman, S.,\& Del Rio, A. (2006). Preservice teachers responses to bullying scenarios: comparing physcal,verbal, and relational bullying. Journal of Educational Psychology, 98(1), 219-231.

Brock, B. L. \& Grady, M. L. (2006). Developing a teacher induction plan: A guide for school leaders . Thousand Oaks, CA: Corwin Press.

Burden, P. R. (2003). Classroom management: Creating a successful learning community (2nded.).). New York, United States of America: John Wiley \& Sons.

Cook, J. (2010). Examining the mentoring experience of teachers. International Journal of Educational Leadership Preparation, 7(1), 1-10.

Crosswell, L. (2009). Classroom management: Developing your own approach to managing the classroom. In J. Millwater \& D. Beutel (Eds.), Stepping out into the real world of education. New South Wales, Australia: Pearson.

Duck, L. (2007). Using sounder foundations to help avoid the why new teachers cry" phenomenon. Clearing House, 81(1), 29-36.

Evans-Andris, M., Kyle, D., \& Carini, R. (n. d. ). (2006). Is mentoring enough? An examination of the mentoring relationship in the pilot two - year Kentucky teacher internship program. The New Educator, 2, 289-309. https://doi.org/https://doi.org/10.1080/15476880600974867

Evertson, C.M.\& Harris, A. H. (1999). Support for managing learning-centered classrooms:The classroom organisation and management program., 59-74.

Fletcher, S. (2000). Mentoring in Schools:A handbook of Good Practice. Routledge,Taylor \&Francis Group (1st Editio). New York, NY10016: Routledge Taylor \&Francis.

Freiberg, H. J. (2002). Essential skills for new teachers. Educational Leadership, 56-60.

Grossman, P. L., \& Thompson, C. (2004). District policy and beginning teachers: A lens on teacher learning. Educational Evaluation and Policy Analysis, 26, 281-301. https://doi.org/doi: $10.3102 / 01623737026004281$.

Hannon, C. (2009). Challenges for teachers in Universal Secondary Education(USE). University of Notre Dam School for International Training.

Hansman, C. A. (2010). Reluctant mentors and resistant protégés: Welcome to the "real" world of mentoring.

Hewitt, P. (2009). Hold on to your teachers. Leadership, 38(5), 12-14.

Ingersoll, R.,\& Strong, M. (2011). The impact of induction and mentoring programmes for beginning teachers: A critical review of the reserach. from 
http://repository.upenn.ed/cgi/viewcontent.cgi?article=1127\&content=gse pub

Ingersoll R., S. T. (2004). Do teacher induction and mentoring matter? NASSP Bulletin, 88(638), 28-40.

Janas, M. (1996). Mentoring the Mentor: A Challenge for Staff Development. Journal of Staff Development, Fall 1996, 17(4).

KatheleenP.Allen. (2010). Classsroom Management, Bully, and Teacher Practices. The Professional Educator, $34(1)$.

Kirkpatrick, L., Lincoln, F.,\& Morrow, L. R. (2006). Assessment of collaborative teacher preparation program: Voices of interns. The Delta Kappa Gramma Bulletin, 36-41.

Larrivee, B. (2005). Authentic Classroom management:creating a learning community and building a reflective practice. Boston: Pearson.

Lewis, R., Romi, S., Qui, X., \& Katz, Y. J. (2005). Teachers' classroom discipline and student misbehaviour in Australia, China, and Israel. Teaching and Teacher Education, 21, 729-741.

Meister, D.G.,\&Melnick, S. A. (2003). National new teacher study: Beginning teachers concerns. Action in Teacher Education, 24(4), 87-94.

Merrett, F.,\& Whedall, K. (1993). How do teachers learn to manage classroom behaviour?.A study of teachers' opinions about their initial training with special refernce to classroom behaviour management. Educational Studies, 19(1), 91-106.

Metros, E. Susan. and Yang, C. (2006a). The importance of Mentors. EDUCAUSE. Ohio state University.

Metros, E. Susan. and Yang, C. (2006b). The importance of Mentors, EDUCAUSE: Ohio state University.

MOES. (2003). Teacher effectiveness. Mentors's Training guide. Kampala: government printer.

MOES. (2004). Teacher effectiveness: Mentors Training Guide. Kampala.: Government Printers.

MOES. (2012). Annual report of the Directorate of Education Standards: Enhancing skills Development. Kampala.

Putman, S. M. (2009). Grappling with classroom management: The orientations of preservice teachers and impact of student teaching. The Teacher Educator, 44(4), 232-247.

Roff, K. A. (2012). The story of mentoring novice teachers in new york. Educational Research and Practice, 2(1), 31-41. https://doi.org/doi:10.5590/JERAP.2012.02.1.03

Rogers, B. (2007). Behaviour management: A whole-school approach. London: : Paul Chapman Publishing.

Stanulis, R.N.,\& Floden, R. E. (2009). Intensive Mentoring as a way to help beginning teachers development balanced instructions. Journal of Teacher Education, 60(2), 112. https://doi.org/10.1177/022487108330553

Stoughto, E. H. (2007). How will I get them to behave?'.Preservice teachers reflect on classroom management. Teacher and Teacher Education, 23, 1024-1037.

Strong, M. (2005). Teacher induction, mentoring, and retention: A summary of the research. The New Educator, 1, 181-198. https://doi.org/doi: 10.1080/15476880590966295

Sugai, G., \& Horner, R. (2002). The evolution of discipline practices: School-wide positive behaviour supports. Child \& Family Behaviour Therapy, 24(1), 23-50.

Villani, S. (2009). Mentoring programs for new teachers: Models of induction and support. Thousand Oaks, CA: Corwin Press, Inc.

Wanberg, C. R., Kammeyer-Mueller, J. D., \& Marchese, M. (2006). Mentor and protégé predictors and outcomes of mentoring in a formal mentoring program. Journal of Vocational Behavior, 69, 410-423. https://doi.org/10.1016/j.jvb.2006.05.010

Wenger, E., McDermott, R.,\&Snyder, W. M. (2002). A guide to managing knowledge: Cultivating communities of practice. Boston: Harvard business School.

Woolnough, H.M and Davidson, M. J. . (2007). Mentoring as career development tool:gender,race and ethnicity implications, in handbook on women in Business and management(eds D. Bilimoria and S.K. Pidevit). Edward Elgar, Cheltenham, 154-177.

\section{Acknowledgement}

I would like to thank God the Almighty for the gift of life and favour that enabled me complete this piece of work. Secondly, I am thankful for the support and guidance of Professor Elizabeth Auma Opiyo and Dr. Echodu Richard. You have helped me understand the value of research and process done the right way. I am both humbled and inspired by the opportunity that Gulu University provided for me. Thank you for your considerations. I also wish to thank DANIDA through Building Stronger University Project for giving me financial support for research work. I would like to thank THRIVE (Training Health Researchers into Vocational Excellence in East Africa) for providing a platform for continuous support through organizing workshops in the area of scholarly writing thank you so much. I am grateful to the secondary school teachers, who participated in the study for the invaluable data they contributed to this study. Thank you so much for your effort.

Copy Right

This piece of work is my original research work, it has never been published in any Journal or Book Chapter. It does not infringe any personal or property rights of another. 